\title{
J01106
}

\section{水素／酸素分圧比センサのガス検知特性の評価 Evaluation of gas sensing characteristics of the hydrogen/oxygen partial pressure ratio sensor.}

○正 鈴木 健吾"1, 丸 祐介*2, 宮崎 洋*1, 杜泰成"1 Kengo SUZUKI ${ }^{* 1}$, Yusuke MARU ${ }^{* 2}$, Hiroshi MIYAZAKI ${ }^{* 1}$ and Yasunari YUZURIHA ${ }^{* 1}$

${ }^{* 1}$ 新コスモス電機 New Cosmos Electric Co., Ltd.

*2 宇宙航空研究開発機構 JAXA Institute of Space and Astronautical Science

Key Words: Hydrogen Sensor, Ceria nanoparticles, Detection threshold in vacuum, Standard conductance element

我々は，真空〜大気圧下で圧力の影響を受けずに水素を検知可能なガスセンサの開発を行っている，センサは 感応材料に酸化物イオン／電子混合伝導体のセリアナノ粒子・焼結体を感応材料に用いて, セリア表面への水素・ 酸素の解離吸着に伴う抵抗值変化を検出する方式で, 窒素や不活性ガスには応答しない特徵を有する ${ }^{1)}$. このセ ンサは水素と酸素の分圧比で抵抗值が決まるので，例えば再使用ロケットのような筐体内部の空気を（酸素）を 窒素や不活性ガスなどで置換した状態 (正常状態)を維持した環境中で水素の漏洩を検知する用途に適している. そこで再使用ロケットへの搭載を想定したセンサユニットを試作しこれの評価を行った.

評価は大気圧，酸素共存下で段階的に水素濃度を上げる方法で行った。評価の結果は，下図に示すとおり水素に 対する応答性と環境中の酸素濃度には規則性が認められることがわかる。この規則性から水素濃度を求める方法 について検討した. センサ出力から水素濃度を求めるには, まず不活性ガスに置換した状態（水素が共存しない 前提）のセンサ出力を酸素濃度情報として取得し, さらにこの状態からの出力の変化を変数とすれば水素濃度を 計測できることを確認した。

センサ出力vs.水素/酸素 濃度比

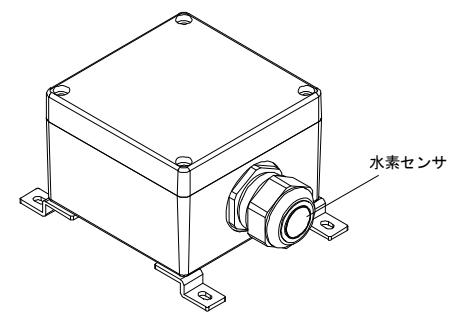

図 1 試作したセンサユニ ット外観

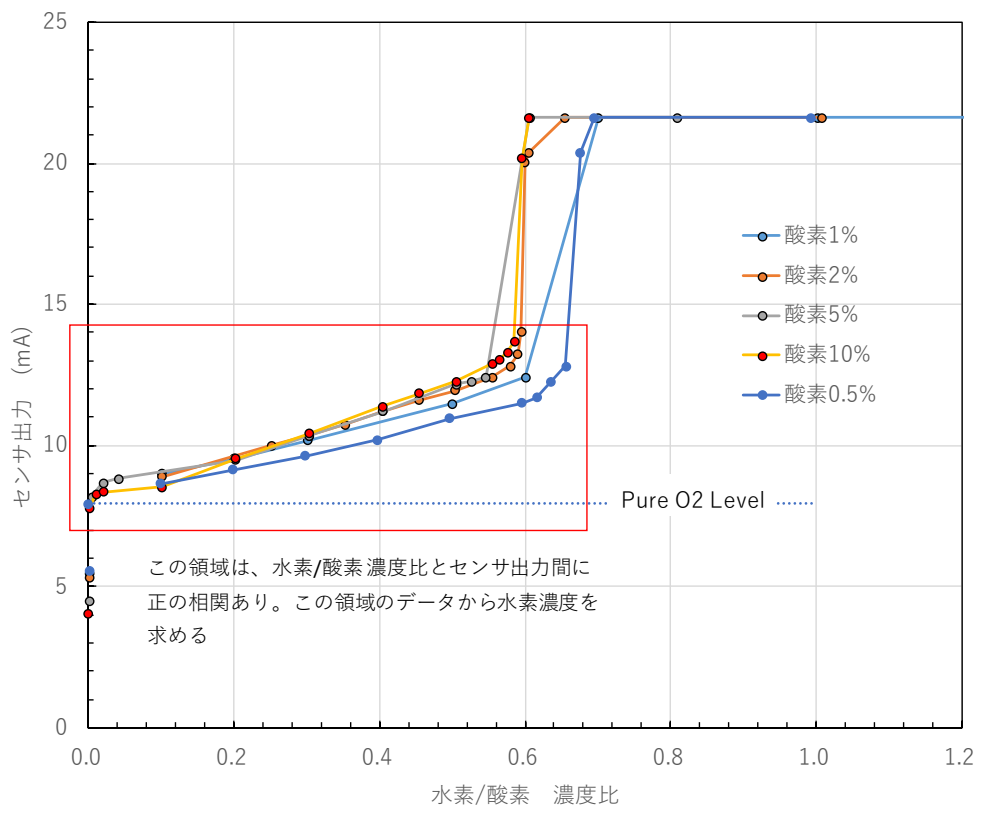

図 2 センサ出力と水素/酸素濃度比の関係

文献

[1] K. Suzuki, et al., Sensors and Actuators B, 250, 617-622 (2017)

[2] K. Suzuki, et al., 第 37 回水素エネルギー協会大会, 予稿集(2017) 